10IKC-361

\title{
EVOLUTION OF THE EARLY CRETACEOUS ALKALINE JASRA COMPLEX, SHILLONG PLATEAU, NORTHEASTERN INDIA
}

\author{
Srivastava $^{1}$ RK, Melluso L ${ }^{2}$, Petrone ${ }^{3}$ CM, Guarino² V, Sinha ${ }^{2}$ AK \\ ${ }^{1}$ Centre of Advanced Study, Department of Geology, Banaras Hindu University, Varanasi 221005, India \\ ${ }^{2}$ Dipartimento di Scienze della Terra, Università di Napoli Federico II, Napoli, Italy \\ ${ }^{3}$ Department of Earth Sciences, Cambridge University, Cambridge, United Kingdom
}

The Early Cretaceous Jasra alkaline-maficultramafic complex, along with other contemporaneous alkaline-carbonatite complexes, is reported to intrude within the Shillong Plateau of northeastern India (Fig. 1a). These complexes are thought to be spatially and temporally associated with a plume currently beneath the Kerguelen archipelago, which was situated very close to the eastern Indian margin at 100-120 Ma and responsible for magmatism in the eastern and northeastern India. This magmatism includes the Rajmahal and Sylhet Trap tholeiitic basalts, exposed above the Gondwana Supergroup, alkaline-carbonatite magmatism of the Shillong Plateau, ultrapotassic magmatism in the Damodar

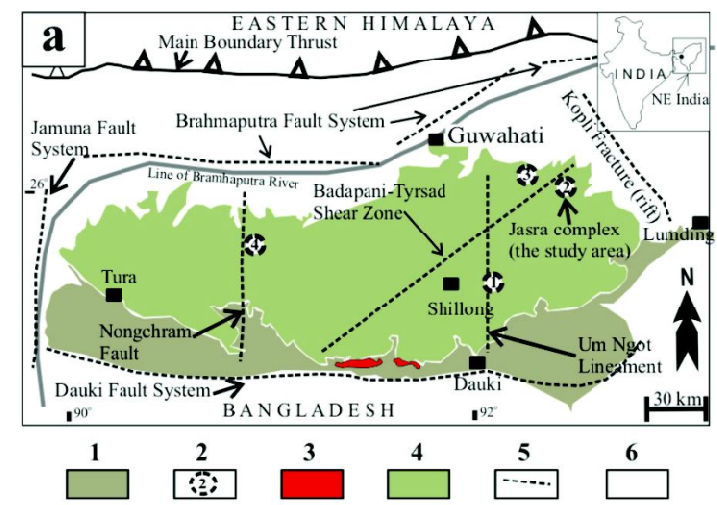

Fig. 1a: Regional geological and tectonic set-up of the Shillong Plateau. 1. Cretaceous-Tertiary sediments, 2. Ultramafic-alkalinecarbonatite complexes, 3. Sylhet basalts, 4. Archaean gneissic complex, Shillong Group rocks, mafic igneous rocks, and Proterozoic granites, 5. Major fault-systems, and 6. Alluvium and recent sediments.
Valley and ultramafic lamprophyres in East Antarctica (Storey et al., 1992; Mitchell, 2007; Srivastava et al., 2005, 2009; Mitchell and Fareduddin, 2009). A U-Pb age of $105.2 \pm 0.5 \mathrm{Ma}$ on zircon/baddeleyite of the Jasra complex is established (Heaman et al., 2002).

Jasra alkaline mafic-ultramafic complex intruded within the Proterozoic Shillong Group and granitoids, and is located within the prominent fracture systems of the Barapani-Tyrsad Shear zone, Kopili fault, and Um Ngot lineaments (Fig. 1b; Srivastava and Sinha, 2004). Broadly this complex comprises pyroxenite, gabbro, mafic dykes and nepheline syenite, however, detailed electron probe studies suggest that rocks of this complex range in composition from olivinephlogopite clinopyroxenites to clinopyroxenites, to essexites, syenites and nepheline syenites. The aim of this work is to achieve information about the nature of the parental magmas which filled the intrusion, the overall chemical affinity, petrogenetic similarities and differences with other alkaline intrusions of the Shillong Plateau and nearby areas belonging to the same magmatic cycle.

Petrographic studies classify rocks of this complex into the following types:

i) Phlogopite-olivine clinopyroxenites (cumulus pale-coloured to purple clinopyroxene and subordinate olivine, with chromite inclusions, surrounded by large poikilitic phlogopite 


\section{0 $^{\text {th }}$ International Kimberlite Conference, Bangalore - 2012}

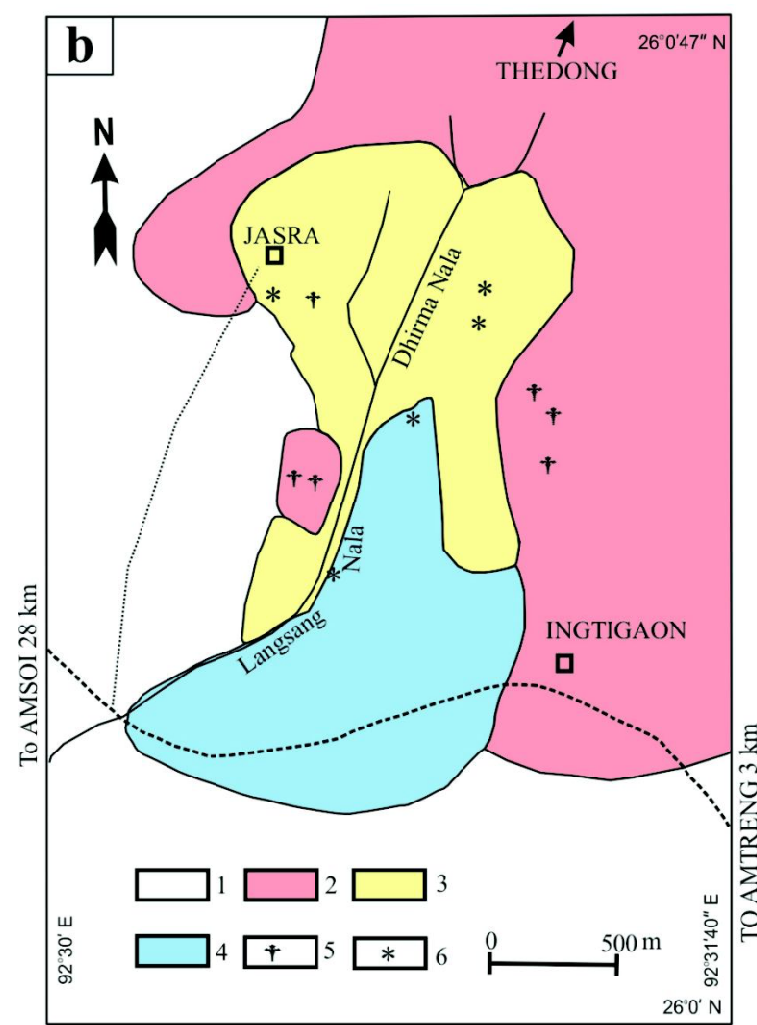

Fig. 1b: Geological map of the Jasra alkaline ultramafic-mafic complex (modified after Srivastava and Sinha, 2004). 1. Shillong Group rocks, 2. Neoproterozoic granite, 3. Pyroxenite, 4. Gabbro,

5. mafic dike exposures, 6. Nepheline syenite exposures.

crystals and intercumulus oxides, apatite, green clinopyroxene, nepheline and titanite),

ii) Phlogopite-bearing clinopyroxenites (cumulus deep green clinopyroxene, with poikilitic phlogopite and interstitial titanite),

iii) Amphibole-bearing gabbroic rocks (colourless to purple cumulus clinopyroxene \pm olivine set in large poikilitic plagioclase crystals, with additional alkali feldspar and rarer nepheline. Brown amphibole is found as rim of clinopyroxene and as large crystals in poikilitic plagioclase), and

iv) Nepheline-bearing syenites/nepheline syenites (nepheline-bearing syenite with rare idiomorphic clinopyroxene, with brown amphibole rim, abundant alkali feldspar and subordinate nepheline).
Bulk rock geochemistry of the Jasra alkaline-mafic-ultramafic complex does not suggest any direct genetic relationship between the different rock units; probably have different genetic histories. The radiogenic isotopic compositions of these rock units suggest that they are derived from the mixing of mantle components such as HIMU and EM. Low-degree melting of a metasomatized mantle peridotite produces carbonatite melts that might dissolve an adequate amount of olivine and pyroxene to provide the $\mathrm{Al}, \mathrm{Fe}$, and Si necessary for crystallization of silicate minerals. The $\mathrm{CO}_{2}$ released by this process progressively metasomatizes the lherzolite to an alkaline wehrlite, and melts derived from alkaline wehrlite (ultrabasic alkaline silicate magma) may be responsible for the crystallization of different rocks of the Jasra Complex (Srivastava and Sinha, 2004, 2007).

The mineral compositions indicate that at least part of the magmatic reservoir of the Jasra intrusion was filled by relatively primitive liquids, as testified by the occurrence ultramafic rocks having olivine very rich in forsterite and with $\mathrm{Cr}$ spinel inclusions. The Mg\# of most magnesian

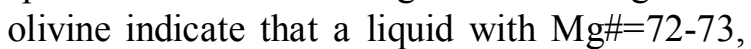
similar to that of primitive magmas filled the magma chamber and formed olivine-bearing ultramafic cumulates. The abundant presence of phlogopite in the ultramafic olivine-bearing rocks, which are usually thought to be early cumulates in magma reservoirs, and its early appearance in the crystallization order, indicate that these rocks were formed by liquids having high potassium and volatile elements. This is not observed in any magma having sodic affinity, and indeed is not noted in any of the Sung Valley rocks (cf. Melluso et al., 2010). Instead, the gabbroic rocks have sodic plagioclase, with also relatively Fe-rich olivine, indicating derivation from evolved magmas, and cores of Mg-rich clinopyroxene (Mg\#=86-87). The Jasra intrusion crystallized in a relatively $\mathrm{H}_{2} \mathrm{O}$-rich magmatic system, which allowed the crystallization of phlogopite and 


\section{0 $^{\text {th }}$ International Kimberlite Conference, Bangalore - 2012}
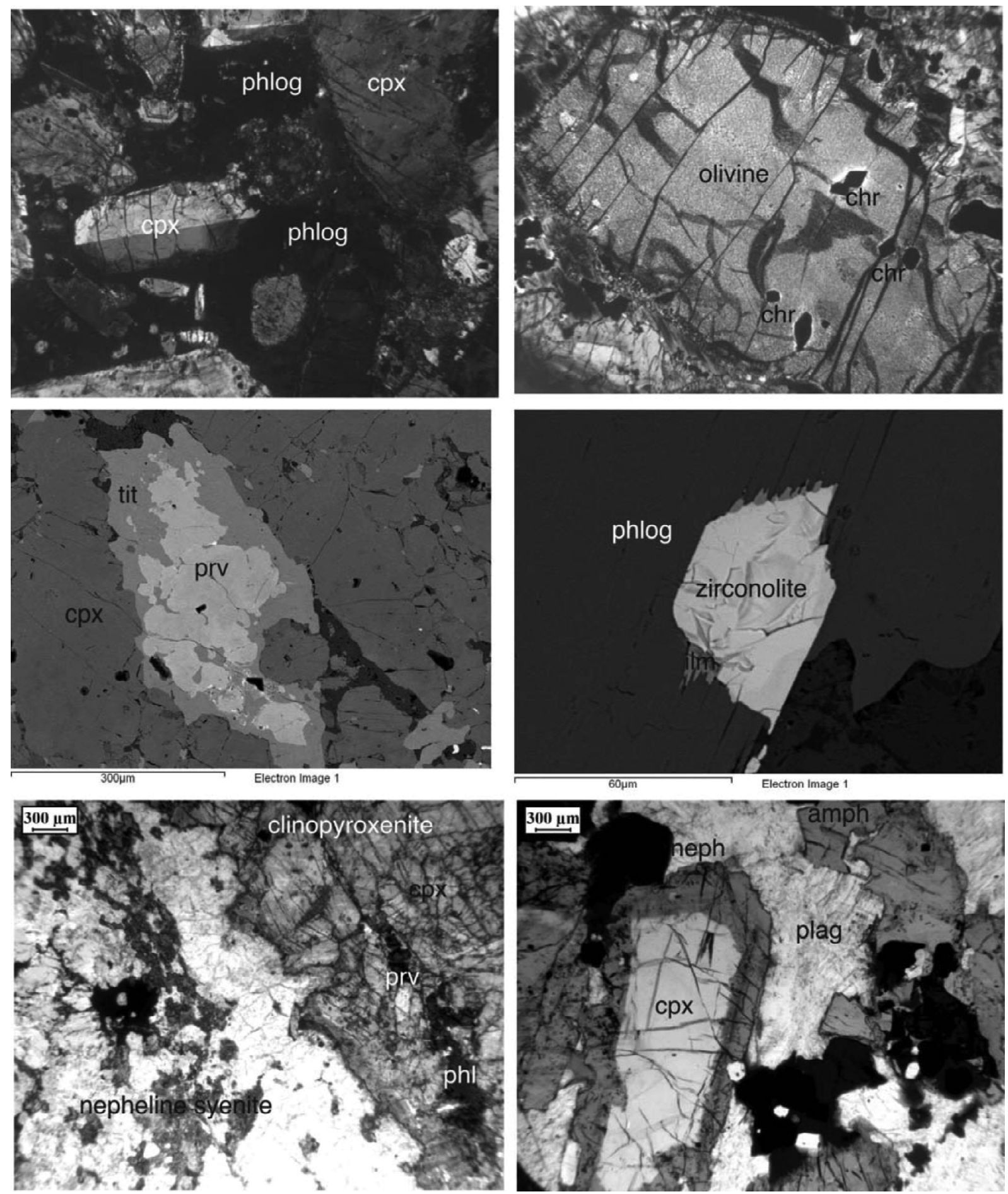

Fig. 2: Photomicrographs of Jasra samples: a) cumulus olivine and clinopyroxene in intercumulus phlogopite; b) olivine included in phlogopite with chromiferous spinel inclusions; c) back scattered image of perovskite with a titanite rim in the clinopyroxenite; d) back scattered image of zirconolite with a thin rim of ilmenite in the alkali gabbro; e) contact between the nepheline syenite and the perovskite-bearing clinopyroxenite; f) zoned clinopyroxene with a Ti-rich rim and kaersutitic amphibole. 


\section{0 $^{\text {th }}$ International Kimberlite Conference, Bangalore - 2012}

kaersutite. The occurrence of kaersutitic amphibole is another feature typical of rocks of within plate alkaline or strongly alkaline series (cf. Melluso et al., 2007; Cucciniello et al., 2011), and its abundance in the gabbroic rocks (and the gabbroic rocks themselves) is one of the main differences with the Sung Valley intrusion.

The Jasra clinopyroxenite also features perovskite with a reaction rim of titanite. It is well known that no theralites or magma equivalents (basanites) can have perovskite, which crystallize from highly silica undersaturated, larnitenormative magmas such as ultamafic lamprophyres, nephelinites and melilitites (cf. Melluso et al., 2008, 2010). This definitely indicates the presence of unrelated magma batches that filled the complex, confirming a more complicated pattern of intrusion than previously thought.

The chemical differences in the mica (and other minerals) compositions of course completely preclude an origin related to the ultrapotassic rocks of the Jharia area, indicating that apparently no lamproitic magmas filled the complex. As an example, the phlogopites of the Jasra rocks have no evolution towards the tetra-ferriphlogopite compositions typical of lamproites (Fig. 3). Nevertheless, the chromite compositions record

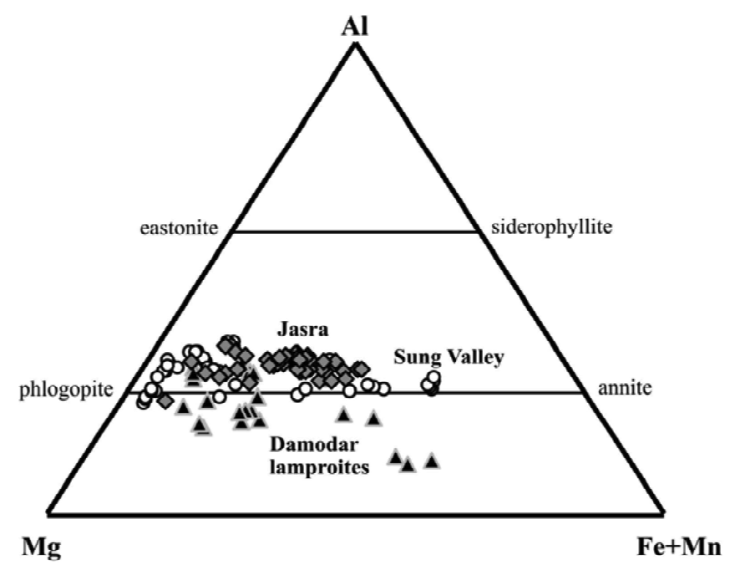

Fig. 3: Phlogopite compositions of the Jasra rocks in the standard Al-Mg-Fe diagram. The Sung Valley and the Damodar mica compositions are are also plotted for comparison. also unusual compositions, which are more typical of lamproites and kimberlites than sodic or potassic alkali basalts. The potassic affinity of the Jasra rocks can be used as evidence of the derivation of the mafic mantle-derived magmas from continental lithosphere, rather than from direct, plume-related volcanic activity We suggest that the impact of the Kerguelen plume beneath this area of India triggered low-degree melting of the most fusible parts of the lithospheric mantle, with the consequent formation of low-volume alkaline-carbonatitic rocks, varying from ultrapotassic to sodic in composition. Therefore, inferred geochemical and isotopic connections between the composition of magmatic products generated by a Kerguelen hotspot and the composition of the alkaline rocks of northeastern India may be hazardous, if not weakly based.

Therefore, it may be concluded that the potassic affinity of the rocks of the Jasra complex is linked to a change in the metasomatic agent in the source, from $\mathrm{CO}_{2}$-rich at Sung Valley, to $\mathrm{H}_{2} \mathrm{O}$ rich at Jasra, indicating regional-scale heterogeneity in the mantle sources of the alkaline volcanism of northeastern India. Thus, there is a variety of magmas which filled the Late Cretaceous intrusions of eastern India: magmas with sodic affinity at Sung Valley, with additional carbonatites, magmas of potassic affinity at Jasra, likely without carbonatites, magmas of ultrapotassic affinity (lamproites) in the Damodar Valley intrusions, again without carbonatites. This apparent compositional pattern could not be linked to sublithospheric magma input in the Cretacous magmatism of northeastern India, at least for the alkaline intrusions.

Acknowledgements: Authors would like to thanks to Roberto de' Gennaro for his help in the microprobe and backscattered electron work at Napoli and Sergio Bravi for his usual ability in thin section preparation. We also thank Ray Kent for his interest to this project and useful advice. The microprobe work at Napoli has been granted by COFIN 2008 grants to L. Melluso. Rajesh K. 


\section{0 $^{\text {th }}$ International Kimberlite Conference, Bangalore - 2012}

Srivastava thanks CSIR, New Delhi (Scheme No. 24(0251)/01/ EMR-II) for financial support during the initial stage of this study.

\section{References}

Cucciniello, C. Melluso, L., Morra, V., Storey, M., Rocco, I., Franciosi, L., Grifa, C., Petrone, C.M. and Vincent, M. (2011) New 39Ar-40Ar ages and petrogenesis of the Massif d'Ambre volcano, northern Madagascar. In. Beccaluva, L., Bianchini, G., Wilson, M. (eds): Volcanism and Evolution of the African Lithosphere. Geological Society of America Special Papers, 479, in press, doi: 10.1130/2011.2478(14).

Heaman, L.M., Srivastava, R.K. and Sinha, A.K. (2002) A precise U-Pb zircon/baddeleyite age for the Jasra igneous complex, Karbi-Anglong district, Assam, NE India. Current Science, 82, 744-748.

Melluso, L., Morra, V., Riziky, H., Veloson, J., Lustrino, M., Del Gatto, L. and Modeste, V. (2007) Petrogenesis of a basanite-tephrite-phonolite volcanic suite in the Bobaomby (Cap d'Ambre) peninsula, northern Madagascar. Journal of African Earth Sciences, 49, 29-42.

Melluso, L., Srivastava, R.K., Guarino, V., Zanetti, A. and Sinha, A.K. (2010b) Mineral compositions and magmatic evolution of the Sung Valley ultramaficalkaline-carbonatitic complex (NE India). The Canadian Mineralogist, 48, 205-229.

Melluso, L., Lustrino, M., Ruberti, E., Brotzu, P., Gomes, C.B., Morbidelli, L., Morra, V., Svisero, D.P. and d'Amelio, F. (2008) Major and trace element composition of olivine, perovskite, clinopyroxene, $\mathrm{Cr}$-Fe-Ti oxides, phlogopite and host kamafugites and kimberlites, Alto Paranaíba, Brazil. The Canadian Mineralogist, 46, 19-40.
Mitchell, R.H. (2007) Potassic rocks from the Gondwana Coalfields of India: closing Pandora's box of petrological confusion? Journal of the Geological Society of India, 69, 505-512.

Mitchell, R.H. and Fareeduddin (2009) Mineralogy of peralkaline lamproites from the Raniganj coalfield, India. Mineralogical Magazine, 73, 457-477.

Srivastava, R.K., Chalapathi Rao, N.V. and Sinha, A.K. (2009) Cretaceous potassic intrusives with affinities to aillikites from Jharia area: Magmatic expression of metasomatically veined and thinned lithospheric mantle beneath Singhbhum Craton, Eastern India. Lithos, 112, 407-418.

Srivastava, R.K., Heaman, L.M., Sinha, A.K. and Shihua, S. (2005) Emplacement age and isotope geochemistry of Sung Valley alkaline-carbonatite complex, Shillong Plateau, northeastern India: implications for primary carbonate melt and genesis of the associated silicate rocks. Lithos, 81, 33-54.

Srivastava, R.K. and Sinha, A.K. (2004) Geochemistry of early Cretaceous alkaline ultramafic mafic complex from Jasra, Karbi Anglong, Shillong Plateau, Northeastern India. Gondwana Research, 7, 549-561.

Srivastava, R.K. and Sinha, A.K. (2007) Nd and Sr isotope systematics and geochemistry of a plumerelated Early Cretaceous alkaline-mafic-ultramafic igneous complex from Jasra, Shillong Plateau, northeastern India. Geological Society of America Special Paper, 430, 815-830.

Storey, M., Kent, R.W., Saunders, A.D., Salters, V.J., Hergt, J.M. Whitechurch, H., Sevigny, J.H.,Thirlwall, M.F., Leat, P.T., Ghose, N.C. and Gifford M. (1992) Lower Cretaceous volcanic rocks on continental margins and their relationship to the Kerguelen Plateau. In Wise, S. W., Jr., Schlich, R., et al. Proceedings of the Ocean Drilling Program, Scientific Results, Vol. 120, 33-47 